УДК $81.23=161$

\title{
ПСИХОЛІНГВІСТИЧНИЙ АНАЛІЗ АСОЦАТИВНОГО ПОЛЯ СТИМУЛУ ЦІННІСТЬ (ДИНАМІЧНИЙ АСПЕКТ)
}

\author{
ТЕРЕХОВА Д. І.
}

кандидат філологічних наук, доцент Київський національний лінгвістичний університет dterekhova@ukr.net

Вивчення мовної свідомості представників різних етносів не втрачає своєї актуальності в сучасній психолінгвістиці. Переважна частина досліджень зазначеної проблеми грунтується на матеріалах асоціативних експериментів, яких з середини минулого століття до сьогодні накопичено чимало і в лексикографічних працях, і в окремих наукових розвідках, що дозволяє вивчати мовну свідомість на певному часовому зрізі і в динаміці. Однак список стимулів не є всеохоплюючим, тому для досягнення мети цієї роботи використано матеріали вільних асоціативних експериментів, проведених в Україні в 2000 та 2012 роках.

У статті подано результати психолінгвістичного аналізу асоціативних полів словастимулу ЦІННІСТЬ, отриманих від українських респондентів з інтервалом у дванадцять років, які репрезентують динаміку змін у відповідних фрагментах образу світу українців.

Структуру асоціативних полів виявлено за допомогою “асоціативного гештальту", який унаочнив тенденції змін у мовній свідомості представників українського етносу на початку XXI століття.

Ключові слова: образ світу, мовна свідомість, асоціативний експеримент, асоціативне поле, асоціативний гештальт.

\section{PSYCHOLINGUISTIC ANALYSIS OF ASSOCIATIVE FIELD OF THE STIMULUS ЦIHHICTЬ (DYNAMIC ASPECT)}

TEREKHOVA Diana Ivanivna PhD in Philology, Associate Professor Kyiv National Linguistic University dterekhova@ukr.net

Introduction. The study of the linguistic consciousness of representatives of various ethnic groups does not lose its relevance in modern psycholinguistics. The overwhelming part of the researches of this problem is based on the materials of associative experiments. There have been accumulated a lot of these experiments both in lexicographical works and in separate scientific researches from the middle of the last century up to now. This fact allows studying of the linguistic consciousness at a certain time slice and in dynamics. However, the list of stimuli is not comprehensive, therefore, the materials of free associative experiments, that was conducted in Ukraine in 2000 and in 2012, have been used, in order to achieve the purpose of this work.

Purpose. The purpose of the study is to reveal the structure of the associative value by the example of the associative fields of the stimulus ЦІННІСТЬ in the Ukrainian language.

Methods. The structure of associative fields was discovered through the "associative gestalt", which made an attempt to illustrate the trends of changing in the linguistic consciousness of the representatives of the Ukrainian ethnic group at the beginning of the 21 st century.

Results. The article presents the results of the psycholinguistic analysis of the associative fields of the word-stimulus ЦІННІСТЬ, that were obtained from Ukrainian respondents with the interval of twelve years, which represent the dynamics of changes in the corresponding fragments of the world image of Ukrainians. 
Conclusion. The study of the meaning of the word on the material of lexicographic sources and a number of associative experiments that were applied to a specific word-stimulus is justified and necessary for the comprehensive identification of semantics.

Key words: the world image, linguistic consciousness, associative experiment, associative field, associative gestalt.

Формулювання проблеми та її зв'язок із науковими завданнями. Дослідження мовної свідомості представників різних етносів вже не одне десятиліття залишається в колі прискіпливої уваги науковців різних галузей, і психолінгвістів зокрема. Особливого значення такі наукові розробки набули в країнах, утворених на пострадянському просторі, оскільки зміни в суспільнополітичному та культурному житті, переоцінка цінностей і визначення нових ціннісних ориєнтирів, пріоритетів в усіх сферах діяльності знаходять відбиття і в мовній свідомості, сприяють самопізнанню та самоудосконаленню внутрішнього світу кожної окремої людини і суспільства в цілому. Осередком духовного життя суспільства науковці вважають цінності, оскільки, будучи засвоєними людьми, вони сприяють згуртуванню соціума, спрямуванню на досягнення спільної мети, таким чином, можуть скеровувати хід історії в певному напрямі. Отже, гуманістичні засади спільноти необхідно не лише вивчати, а й формувати крізь випрацьовану систему цінностей. Виявити цінності представників певного народу дають змогу психолінгвістичні методи дослідження, до яких звертаємося в роботі.

Мета статті та її завдання. Метою цієї наукової розвідки є аналіз асоціативних полів стимулу ЦІННСТЬ, отриманих від українських респондентів в 2000 та 2012 роках задля виявлення змін у відповідних фрагментах образу світу представників українського народу.

Матеріал дослідження отримано в результаті проведення психолінгвістичних експериментів в Україні, як і зазначалося вище, у різні роки - в 2000 ma 2012 роках.

Актуальність дослідження визначається всебічним вивченням мовної свідомості представників як окремого народу, так і в зіставленні з іншими, у психолінгвістиці кінця ХX початку XXI століть. Надійним “інструментом” дослідження мовної свідомості визнано асоціативний експеримент. На матеріалах, отриманих у такий спосіб, створено асоціативні словники, які репрезентують мовну свідомість представників певного етносу в конкретний історичний період. Наприклад, в українській лексикографії широко відомі словники Н.П. Бутенко “Словник асоціативних норм української мови” (1979) та “Словник асоціативних означень іменників в українській мові” (1989), С. Мартінек “Український асоціативний словник” у двох томах (2007). Почасти україномовний матеріал репрезентує “Славянский ассоциативный словарь: русский, белорусский, болгарский, украинский” (2004) за редакціїю Н.В. Уфимцевої, Г.О. Черкасової, Ю.М. Караулова, С.Ф. Тарасова. Отже, зіставляючи дані словників, виданих у різні часи, можна простежити зміни, що відбулися за певний період у мовній свідомості, з'ясувати їхні причини. Проте повне всебічне дослідження таких змін навряд чи можливе, оскільки списки слів-стимулів у словниках не завжди збігаються, тому більшою мірою йдеться про вивчення динаміки мовної свідомості на матеріалі окремих асоціативних полів або ж, як у нашому випадку, відповідно до мети та завдань роботи слід опиратися на експериментальний матеріал, зібраний власноруч з визначеним інтервалом у часі.

Аналіз останніх досліджень і публікацій засвідчує зацікавлення науковців виявленням змін у мовній свідомості представників різних етносів (напр., див. роботи: Волковинська Н.О. на матеріалі англійської мови; Заєць Г.І. - на матеріалі україської мови; Уфімцева Н.В. на матеріалі російької мови; Терехова Д.І. - на матеріалі східнослов’янських мов; Молдалієв О., Сандибаєва Н.О. - на матеріалі казахської мови та ін.). Отже, у нашій роботі акцентовано увагу на змінах у мовній свідомості представників молодого покоління українців, становлення яких відбувалося в незалежній країні, тому вивчення їхніх ціннісних пріоритетів $\epsilon$ важливим і необхідним з огляду на те, що саме молодь визначатиме свою долю, долю країни у майбутньому. 
Розвиток наукової думки в пострадянський період у різних галузях науки спонукає до всебічного вивчення цінностей (загальнолюдських, європейських, національних тощо) окремо або у взаємодії та взаємозалежності, що зумовлено потребами становлення країни та формування світогляду іiі громадян. Огляд праць засвідчує значний доробок учених у багатьох аспектах дослідження цінностей, зокрема у філософському (напр.: Альчук М.П., Бойченко Н.М., Висоцька О.Є., Кафарський В.І., Кодієвська Е.А., Лазарєва А.О., Мацько Д.С., Нікітенко В.О., Носенко О.В., Ременець О.В., Юшкевич Ю.С.), історичному (напр.: Калашнікова В.С., Себта Т.М.), психологічному (Чхаїдзе А.О.), юридичному (Жебровська К.А., Зверховська В.Ф., Овчиннікова А.П., Реньов С.В., Романюк А.О.), соціологічному (Дмитрук Н., Лутаєв В.В., Морозова Т.Г., Циганчук А.С.), етичному та релігійному (Аболіна Т.Г., Гайдукевич К.А., Ткачук В., Яковенко А.І.), педагогічному та методичному (Антоненко Т.А., Безугла М.В., Гришко Ю.А., Канішевська Я.В., Лебідь І.В., Носенко Є.Л., Осіпцов А.В., Роман С.В., Павліченко О.М., Піроженко Т.О., Сліпець П.П., Ускова АЛ., Химич Н.С.), лінгвістичному (Бєліков В.І, Буряковська В.А., Дикін Р.В., Дячук О.В., Карасик В.І., Осовська І.М., Почепцов Г.Г.). 3 огляду на історичні зміни, які відбулися в політичній, суспільно-економічній, культурній та інших сферах наприкінці ХХ століття з розпадом СРСР і формуванням незалехних держав, надзвичайно важливим видається вивчення змін у ціннісних орієнтирах народів цих держав, і виявити ці зміни у мовній свідомості дає змогу психолінгвістичний підхід.

Наукові результати виявляються у встановленні змін в образах мовної свідомості українців у перше десятиліття XXI століття, які відбивають ціннісні пріоритети молоді.

Виклад основного матеріалу дослідження. У “Філософському енциклопедичному словнику” (Шинкарук, 2002, с. 708-709) цінність визначається, як “термін, що позначає належне та бажане, на відміну від реального, дійсного”. За даними цього джерела, розуміння цінності було започатковано ще в античності Платоном, який розумів ідею добра як таку, що “увінчує ієрархію всіх інших ідей”. У період середньовіччя цінності вважалися ідеями, які “..Бог привніс у світ внаслідок акту творення світу та через явлення Христа - зокрема через Божий Заповіт”. (Шинкарук, 2002, с. 708) У новочасній філософії дотримувалися суб' єктивістського розуміння цінностей: “...цінності належать до психічних об’єктів - їх джерелом є наші бажання, інтереси, почуття, ставлення” (Шинкарук, 2002, с. 708). У подальшому сформувалися два погляди на природу цінностей: суб’єктивістський та об’єктивістській. ...” У філософії кін. ХХ ст. суперечка двох названих підходів до проблеми цінностей існувала у вигляді певних тенденцій. Більшість сучасних філософів у поясненні природи цінностей намагаються поєднати позитивні елементи обох підходів. За висловом Фрондізі, складність цінностей, поєднання в них різнорідних елементів спонукала “пояснювати природу цінностей на основі поняття гештальту” (Шинкарук, 2002, с. 708). Цінності поділяють на дві групи: “нижчі”, або “матеріальні”, які задовольняють біологічні потреби, і вищі (духовні) цінності; на індивідуальні, колективні (партикулярні) та універсальні (загальнолюдські). Універсальні визнають різні народи, а партикулярні $\epsilon$ самобутними для певного народу. Універсальні “включені в контекст кожної із культур, націй чи цивілізацій” (Шинкарук, 2002, с. 709).

Цінності є важливою основою для єднання людей у нації, цивілізації. Особливої уваги надається моральним цінностям, які характеризують як: “1) осмислені моральною свідомістю, етично обгрунтовані належні доброчесності й відповідні їм норми поведінки (мудрість, мужність, толерантність, вірність, правдивість, щирість та ін.); 2) узагальнений зміст основних етичних понять (добро і зло, справедливість, щастя, гідність, честь, обов'язок тощо) і принципів (альтруїзм, гуманізм, благоговіння перед життям та ін.); 3) безпосередньо значимі для людини універсальні зразки, вимоги, ідеали моралі, які мають самостійний статус, схвалюються суспільною думкою, знаходять втілення в праві, релігії, мистецтві, філософії” (Шинкарук, 2002, c. 709). 
У “Словнику сучасної української мови” у багатозначного слова ЦіННІСТЬ зафіксовано три основних значення:

Ці́нНІСТЬ, ності, жін.

1. Виражена в грошах вартість чого-небудь; ціна. Посилка з оголоменою цінністю...

2. перев. мн. Те, що має певну матеріальну або духовну вартість. Творилися нові сили в народі, народжувалися нові иінності (Ірина Вільде, Б'є восьма, 1945, 83 // Цінний предмет. В той же день конфісковані иінності було відправлено в Херсон і здано губернському казначею по акту (Олесь Гончар, II, 1959, 74). Матеріальні цінності, ек. - всі предмети (земля, будівлі, речі побуту і т. ін.), що мають певну вартість, ціну. Скільки матеріальних иінностей, а з ними і людського щастя принесла ота дружба наукових праиівників з колгоспом (Іван І. Волошин, Озеро.., 1959, 51).

3. Важливість, значущість чого-небудь. ... Твори найкрупніших майстрів портрета - Рєпіна або Серова, Веласкеса або Рембрандта - не втратили і ніколи не втратять для нас своєї цінності через те, ще в них, крім великоїмайстерності, відчувається світогляд епохи, система поглядів художників (Мистецтво, 1, 1959, 34). Надавати цінності - те саме, що Надавати значення. Надаючи великої иінності люиерні, як надійному джерелу кормів, радгосп розширив iï посіви до шестисот гектарів (Хлібороб України, 2, 1969, 6); Переоцінка [всіх] цінностей; Переоцінювання [всіх] цінностей - те саме, що Переоцінка [всіх] цінностей. Іде напружене переоцінювання иінностей (Василь Еллан, II, 1958, 177); Переоцінювати (переоцінити) [всі] цінності див. (“Словник української мови”, с. 237).

Психологічно реальне значення слова ЦІННОСТІ, шо існують у мовній свідомості певних людей, зазвичай дізнаються за допомогою асоціативних експериментів. Зупинімося на результатах вільних асоціативних експериментів, проведених в Україні в 2000 та 2012 роках серед студентів вищіх навчальних закладів (було залучено по сто респондентів) для з'ясування образів мовної свідомості, що стоять за словом-стимулом ЦІННОСТІ, та зіставимо ядерну зону і структуру асоціативних полів, одержані у зазначені вище роки.

Асоціативне поле стимулу ЦІННІСТЬ (2000р.) складається зі 100 реакцій, містить 58 асоціатів та 38 одиничних реакцій. Асоціативне поле стимулу ЦІННІСТЬ (2012р.) також складається зі 100 реакцій, містить 56 асоціатів та 41 одиничну реакцію. Порівняємо ядра асоціативних полів (див. табл. 1).

Таблиця 1

Зіставлення ядер асоціативних полів стимулу ЦІННІСТЬ, одержаних у результаті проведення експериментів у різні роки

\begin{tabular}{|c|c|c|}
\hline $\begin{array}{c}\text { № } \\
\text { п/п }\end{array}$ & $\begin{array}{c}\text { Ядро асоціативного поля } \\
\text { стимулу ЦІННІСТЬ (2000 р.) }\end{array}$ & $\begin{array}{c}\text { Ядро асоціативного поля } \\
\text { стимулу ЦІННІСТЬ (2012 р.) }\end{array}$ \\
\hline 1. & здоров'я (8) & життя (9) \\
\hline 2. & життя (7) & сім'я (7) \\
\hline 3. & золото (6) & лровов (6) \\
\hline 4. & вартість (4) & мораль (4) \\
\hline 5. & любов (4) & \\
\hline 6. & гроші (3) & \\
\hline 7. & моральна (3) & \\
\hline
\end{tabular}

Отже, найчастотніші асоціації показують найбільш значущі поняття при сприйнятті стимулу ЦІННІСТЬ. Так, найбільшою цінностю для респондентів у 2000 р. вважалося здоров'я (ЦІННІСТЬ - здоров'я (8)), другою за значустістю $є$ цінність людського життя (ЦІННІСТЬ життя (7)). Окремі реакції пов 'язані з матеріальними циінностя ми (ЦІННІСТЬ-золото (6), 
Терехова Д. I. Психолінгвістичний аналіз асоціативного поля стимулу ЦІННІСТЬ (динамічний аспект)

вартість (4), гроші (3)), однакморальні изінності також були важливими для украӥнців того часу (ЦІННІСТЬ - моральна (3)) та до найвищих цінностей віднесено також любов (ЦІННІСТЬ любов (4)).

Пріоритети респондентів у 2012 р. дещо змістилися: найбільшими цінностями для них є людське життя, родина і любов (ЦННІСТЬ -життя (9), сім'я (7), любов (4)). Важливими $\epsilon$ також матеріальні цінності (ЦІННІСТЬ - гроші (5)) $i$ моральні (ЦІННІСТЬ - мораль (4)).

Аналіз структури асоціативних полів виконано за допомогою методики “асоціативного гештальту” (iї опис подано неодноразово у попередніх статтях). Результати представлено у таблиці 2.

Таблиця 2

Зони гештальтів асоціативних полів стимулу ЦІННІСТЬ, одержаних у результаті проведення експериментів у різні роки

\begin{tabular}{|c|c|c|c|}
\hline № ח/п & Зони гештальтів & 2000 p., $\%$ & 2012 p., $\%$ \\
\hline 1. & Матеріальні цінності & 25 & 19 \\
\hline 2. & Ознаки & 14 & 2 \\
\hline 3. & Характеристики & 10 & 3 \\
\hline 4. & Ставлення & 9 & 8 \\
\hline 5. & Здоров'я & 8 & 1 \\
\hline 6. & Життя & 7 & 9 \\
\hline 7. & Моральні цінності & 12 & 12 \\
\hline 8. & Люди & 4 & 4 \\
\hline 9. & Якості людини & 4 & 2 \\
\hline 10. & Чac & 1 & 2 \\
\hline 11. & Жанр літературного твору & 1 & - \\
\hline 12. & Фізичний стан людини & 1 & - \\
\hline 13. & Влада & 1 & - \\
\hline 14. & Сім'я & - & 8 \\
\hline 15. & Міжособові стосунки & - & 6 \\
\hline 16. & Воля & . & 2 \\
\hline 17. & Вартість & - & 1 \\
\hline 18. & Знання & - & 1 \\
\hline 19. & Частини тіла & - & 1 \\
\hline & Усього зон & 13 & 17 \\
\hline
\end{tabular}

Загальна кількість зон у гештальтах відрізняється: виявлено 13 зон у гештальті асоціативного поля, одержаного в 2000 р., 17 зон - у гештальті асоціативного поля, одержаного в 2012 р. Десять зон наявні в обох гештльтах, однак відрізняються вони обсягом реакцій, отже, й рейтингом у межах гештальту, якісним наповненням - різноманітними реакціями.

Найбільшими за обсягом зонами - ядрами асоціативних полів - виявилися в гештальті асоціативного поля, одержаного в 2000 р., зона 1 "Матеріальні цінності”, 25 \%, зона 2 “Ознаки”, 14 \%; у гештальті асоціативного поля, одержаного в 2012 р., зона “Матеріальні цінності”, 19 \%, "Моральні цінності", $19 \%$.

При зіставленні асоціацій зон "Матеріальні цінності (25 \% і 19 \%) бачимо, наприклад, такі реакції, напр.: ЦІННОСТІ (2000) - золото (6), гроші (3), коштовність (2), папери (2), подарунок (2), антикваріат (1), прикраси (1), рубін (1), скарб (1) / ЦІННОСТІ (2012) - гроші (5), золото (2), скарб (2), валюта (1), прикраси (1), антикваріат (1), годинник (1), ваза (1), які у поєднанні з частотністю становлять певну невідповідність.

Матеріальним цінностям зазвичай протиставляються моральні, тобто такі поняття, що є певним зразком, орієнтиром у житті. Саме вони визначають твердість моральних позицій 
особистості, іï принципи, уподобання, $€$ критерієм вчинків. Вони виражають моральний бік особистості, іiї поведінку. Отже, зони “Моральні цінності" мають однаковий обсяг реакцій, по $12 \%$, проте в ієрархіії зон відповідно до свого рангу займають посідають різні місця. Якісне наповнення також маєвідмінності, напр.: ЦІННОСТІ (2000) - любов (4), мораль (2), віра (1), кохання (1), людяність (1), моральність (1), надія (1) / ЦІННОСТІ (2012) - любов (6), мораль (4), духовність (2), духовне (1), доброта (1).

Ще одна зона "Люди" має однаковий обсяг у двох гештальтах - 4 \% - i містить реакції, що висвітлюють споконвічні загальнолюдські цінності: ЦІННОСТІ (2000) - батьки (1), людина (1), рідня (1) / ЦІННОСТІ (2012) - батьки (2), діти (2). Ідею сімейних цінностей підтримуе зона, наявна лише в гештальті асоціативного поля, одержаного в 2012 р., “Сім’я”, 8 \%: ЦШННОСТІ (2012) - сім'я (8).

Більш важливими для українських респондентів стали й міжособистісні стосунки, реакції цієї зони “Міжособові стосунки”, 6 \%, наступні: ЦІННОСТІ (2012) - дружба (3), стосунки (1), турбота (1), поради (1).

Серед споконвічних цінностей в українських респондентів у 2012 р. зазначено у зоні "Воля", 2 \% ЦІННОСТІ (2012) - воля (2), що засвідчує світоглядні позиції представників українського етносу, самоусвідомлення і визначення ролі в житті.

Висновки та перспекиви подальших досліджень. Таким чином, простежуючи динаміку в мовній свідомості українських репондентів, що відбулася протягом 12 років, зазначимо, що відповідно до результатів експерименту в пріоритеті залишаються матеріальні цінності, хоча їхня значущість дещо зменшилася (з $25 \%$ до $19 \%$ ). У то й же час важливу роль відіграють моральні, духовні цінності, виявлено зсув у бік цінностей людського життя, родини, міжособових стосунків, рис характеру, ствердження волі. Зрозуміло, що кількість респондентів в експериментах обмежена, отже ніяким чином висновки не поширюємо на весь народ, проте виявлені тенденції видаються нам важливими для кращого розуміння процесів, що відбуваються в суспільстві.

Зауважимо, що ціннісні оріснтири респондентів простежуються не лише в асоціативному полі цього стимулу, а й інших асоціативних полів досліджуваних слів-стимулів. У подальшому зіставлення динаміки у мовній свідомості українців плануємо зіставити з такими ж процесами, що відбуваються у мовній свідомості представників інших етносів.

\section{ЛIТЕРАТУРА}

Надольний, І. Ф. (Ред.). (1997). Філософія. Київ: Вікар.

Шинкарук, В. І. (Ред.). (2002). Філософський енциклопедичний словник. Київ: Інститут філософії ім. Г.С. Сковороди НАНУ.

Словник украӥнської мови [в 11 т.]. Т 11, 1980. С. 237.

\section{REFERENCES}

Nadol'nyj, I. F. (Red.). (1997). Filosofiia. Kyiv: Vikar.

Shynkaruk, V. I. (Red.). (2002). Filosofs'kyj entsyklopedychnyj slovnyk. Kyiv: Instytut filosofii im. H.S. Skovorody NANU.

Slovnyk ukrains'koi movy [v 11 t.]. T 11, 1980. S. 237.

Дата надходження до редакиії 15.03.2018 р. Ухвалено до друку 27.04.2018 p. 